\title{
Effect of Turmeric rhizome (Curcuma longa) powder and coconut oil mixture on growth performance, haematological and biochemical parameters of noiler birds
}

\author{
Oyebanji, B. O.*, Oyewumi Oluwaseun, C. and Fadopemu, O. C. \\ Department of Animal Sciences, Obafemi Awolowo University, Ile-Ife, Nigeria. \\ *Corresponding author. Email: Oyebanji.bukola44@gmail.com, Tel: +2347032765674.
}

Copyright (C) 2018 Oyebanji et al. This article remains permanently open access under the terms of the Creative Commons Attribution License 4.0, which permits unrestricted use, distribution, and reproduction in any medium, provided the original work is properly cited.

Accepted 2nd June, 2018; Accepted 22nd June, 2018

\begin{abstract}
This study was conducted to assess the effect of Curcuma longa on growth performance, haematological and biochemical parameters of noiler birds. A total of sixty-four (64) noiler birds of both sexes with an average weight of $1974 \pm 0.03 \mathrm{~g}$ were randomized into four treatment groups. Each treatment group comprised of eight birds per replicate and was replicated twice. Treatment 1 (control), treatment 2 (turmeric at $10 \mathrm{~g} / \mathrm{kg}$ of feed), treatment 3 (turmeric at $20 \mathrm{~g} / \mathrm{kg}$ of feed) and treatment 4 (selcon forte at $0.5 \mathrm{~g} / \mathrm{kg}$ of feed). Weekly body weight and daily feed intake of the birds were recorded for 6 weeks, after which daily weight gain and the feed conversion ratio were calculated. At the end of the feeding trial, blood samples were collected for hematology and biochemical parameters, whole blood was analyzed for hematological parameters while serum was used for biochemical parameters. There was no significant difference $(p>0.05)$ in the daily weight gain and the feed intake of the birds in all the treatments. The packed cell volume (PCV) of birds administered $10 \mathrm{~g}$ of turmeric per $\mathrm{kg}$ of feed (T2) (35.00 $1.88 \%)$ was significantly higher when compared with birds in treatments T1 $(31.09 \pm 2.3 \%)$, T3 $(33.17 \pm 0.79 \%)$ and T4 $(31.33 \pm 2.23 \%)$. The hemoglobin value of T2 birds $(11.48 \pm 0.67$ $\mathrm{g} / \mathrm{dl}$ ) was also significantly higher than birds in the other groups. The total protein of birds in groups T2 $(5.28 \pm 0.45 \mathrm{~g} / \mathrm{dl})$ and T3 $(5.63 \pm 0.34 \mathrm{~g} / \mathrm{dl})$ were significantly $(\mathrm{p}<0.05)$ higher compared to birds in groups T1 $(5.03 \pm 0.48 \mathrm{~g} / \mathrm{dl})$ and T4 $(4.93 \pm 0.40 \mathrm{~g} / \mathrm{dl})$. The birds fed diets supplemented with turmeric (T2 and T3) had significantly low total cholesterol level and higher value of high density lipoprotein and reduced the level of low density lipoprotein when compared to T1 and T4 birds. It can be concluded that turmeric fed to noiler chickens have no deleterious effect and can be included in their feed at $10 \mathrm{~g} / \mathrm{kg}$.
\end{abstract}

Keywords: Biochemical, Curcuma longa, growth performance, hematological, noiler.

\section{INTRODUCTION}

The poultry sub-sector is the most commercialized of all of Nigeria's agricultural sub-sectors. The livestock sector is vital to the socio-economic development of Nigeria. It contributes about 9 to $10 \%$ of agricultural Gross Domestic Product (GDP) (Adene and Oguntade, 2006). Phytogenic feed additives such as herbs and spices are commonly incorporated into the diets of agricultural livestock, particularly swine and poultry, to improve flavour and palatability, therefore enhancing productive performance (Windisch et al., 2008). Herbs and spices are well identified to exert potent antimicrobial properties in vitro against various pathogens, and as alternative feeding strategy to replace antibiotic growth promoters ( $\mathrm{Si}$ et al., 2006; Lee et al., 2013). In the study carried out by Adodo (2002) and Omojasola and Awe (2004), it was noted that there has been resurgence of interests for "all natural" medicinal plants like herbal feed additives, plant extracts with growth, flavour, colour enhancing, antioxidant and antibacterial activities because there is an increase of interest to find non-synthetic alternatives for antibiotics between the scientists.

Turmeric (Curcuma longa) is a tropical plant native to 
southern and southeastern tropical Asia. The main yellow bioactive substances isolated from the rhizomes of Curcuma are curcumin, demethoxycurcumin and bisdemethoxycurcumin which is present to the extent of 2 to $5 \%$ of the total spice in turmeric powder. Curcumin is the main important bioactive ingredient responsible for the biological activity of turmeric. Curcumin has been shown to have several biological effects, exhibiting antioxidant (Ak and Gulcin, 2008) antibacterial (Lal et al., 2012), antimalarial (Mishra et al., 2008), antiviral (Singh et al., 2010), antitumor (Aggarwal et al., 2004), hepatoprotective (Girish and Pradan, 2012), renoprotective (Trujillo et al.,2013) and hypocholesterolemic (Kim and Kim, 2010). It is also used in gastrointestinal and respiratory disorders (Anwarul et al., 2006). The significant biological properties of turmeric powder make it a potential substitute for in-feed antibiotics in livestock diets. Although curcumin possesses an exceptional pharmaco-dynamic profile, its use has been limited by an extremely low aqueous solubility and poor bioavailability, rapid clearance, and low cellular uptake (Ahmad et al, 2015). To improve the bioavailability of curcumin, numerous approaches have been undertaken. These approaches involve the use of adjuvant like piperine that interferes with glucuronidation; the use of liposomal curcumin; curcumin nanoparticles; the use of structural analogues of curcumin (EF-24) (Anand et al., 2007) and the use of curcumin phospholipid complex. The fat-soluble quality of curcumin makes turmeric more potent when consumed in combination with healthy fat like avocado, coconut oil, olive oil etc (Renter, 2013). Coconut oil, or copra oil is an edible oil extracted from the kernel or meat of mature coconuts harvested from the coconut palm (Cocos nucifera). According to Rahmani, (2018), there is still the need for detailed studies to improve the efficacy, safety, and mode of action of curcumin in diseases prevention and management.

Noiler chicken is a dual purpose breed of chicken developed by Amo Farm Sieberer Hatchery Limited for small holders to address the challenges of food insecurity and financial dependency among rural populace, especially women. Noiler is bred to survive on low quality feedstuffs to provide good quality meat and egg. Knowledge of bird haematology and biochemical are useful diagnostic tool in veterinary medicine, and these values can be used as physiological indicators (Hrabcakova et al., 2014). Hence this study was designed to evaluate the effect of turmeric powder mixed with coconut oil on growth performance, haematological parameters and biochemical parameters of noiler chickens.

\section{MATERIALS AND METHODS}

\section{Experimental site/location}

This research was carried out at the poultry unit of Teaching and Research Farm of Obafemi Awolowo
University, Ile-Ife, Osun State, Nigeria. Ile- Ife lies on longitude $4^{\circ} 69^{\prime} \mathrm{E}$ and latitude $70^{\circ} 50^{\prime} \mathrm{N}$.

\section{Experimental design}

Sixty-four growing birds of noiler breed with an average weight of $1974 \pm 0.03 \mathrm{~g}$ were purchased from Teaching and Research Farm of Obafemi Awolowo University, Ile-Ife and were randomly allotted using Complete Randomized Design into four groups tagged as Treatments $(T) 1$ to 4 and were replicated two times. Each replicate consists of eight birds comprising 5 males and 3 females, the experiment lasted for six weeks.

\section{Experimental diet and feeding}

Poultry feed (broiler finisher) was used throughout the experiment, $21 \% \mathrm{CP}$ and $3100 \mathrm{Kcal} / \mathrm{kg}$. Coconut oil and turmeric powder were added as experimental materials. The following were the breakdown of experimental materials added to the feed per bird per day:

Treatment 1 were administered coconut oil at $1 \mathrm{ml}$ per bird. Treatment 2 were administered turmeric powder at $10 \mathrm{~g} / \mathrm{kg}$ of feed and coconut oil at $1 \mathrm{ml}$ per bird.

Treatment 3 were administered turmeric powder at $20 \mathrm{~g} / \mathrm{kg}$ of feed and coconut oil at $1 \mathrm{ml}$ per bird.

Treatment 4 were administered selcon forte at $0.5 \mathrm{~g} / \mathrm{kg}$ of feed and coconut oil at $1 \mathrm{ml}$ per bird.

The feed was given at $5 \%$ of body weight and water was supplied ad libitum. Selcon forte is a unique combination of Selenium-Zinc-Yeast fortified with Copper, Natural Vitamin-E and Leptidinia reticulata used by farmers as growth promoter and immune booster.

\section{Extract preparation}

\section{Coconut oil}

Mature coconuts were purchased from the Ojatuntun, IleIfe, Osun state, located in the South West of Nigeria. The coconuts were cut open and the kernel meats (Endosper) were removed. The kernel meats were blended and poured into a bowl. Hot water was added to it and the mixture was sieved to remove the shaft. The milky solution obtained was kept in the refrigerator for few hours until a cake crust was formed on top of the solution. The cake was then scraped and heated until a clear, transparent liquid was obtained.

\section{Turmeric powder}

Rhizomes of Curcuma longa were purchased from the Ojatuntun, Ile-Ife, Osun state, located in the South West of 
Nigeria. The rhizomes were cut into small sizes and oven dried at $50^{\circ} \mathrm{C}$ for 12 hours to a moisture content of 11 to $13 \%$ at the Animal Sciences Meat Laboratory. Then, the rhizomes were grinded to obtain a golden yellow powder.

\section{Extract administration}

The coconut oil was measured using Syringe, the turmeric powder and Selcon forte were weighed by means of weighing balance. The extracts were administered daily in feed to the varying experimental units as stipulated in the experimental model.

\section{Sample collection and analyses}

The birds were weighed weekly and at the end of the experiment, blood was collected through the wing veins using disposables syringes and needles. The blood samples were collected into sample bottles one without and one with dipotassium salt of ethylene diamine tetra acetic acid (EDTA) which served as anticoagulants. Hematological indices were estimated using standard procedures (Jain, 1986) for its hemoglobin, red blood cells (RBC), packed cell volume (PCV) and white blood cells (WBC) contents. Feed conversion ratio was calculated to measure the efficiency with which the bodies of livestock convert animal feed into the desired output. It was calculated as average feed intake per daily weight gain

\section{Procedure for blood collection used for hematological parameters}

$2 \mathrm{ml}$ of blood was collected from the jugular vein of the birds and was put directly into EDTA tube for hematological analysis.

\section{Packed Cell Volume (PCV)}

A microcapillary tube was filled with uncoagulated blood and the end was sealed with plasticine. The tube was centrifuged in a micro hematocrit centrifuge. The plasma at the top of the capillary tube could be used for determining plasma protein and fibrinogen and for assessing plasma colour and turbidity. The level of the settled blood cells was read by placing the tube on the hematocrit graphic reader.

\section{Erythrocyte counts}

The red blood cell count per million was done using blood containing anticoagulants by the haemocytometer method. A red cell pipette was used to draw blood up to 0.5 mark and was dropped on a glass slide, smeared and was covered with a cover slip. This was viewed under the microscope. The erythrocytes in the five lower squares were counted. The volume counted was calculated using the formula below:

$$
\mathrm{RBC}=\frac{\text { Total number of cell count } \mathrm{x} \text { dilution factor }}{\text { Volume } 0.02 \mathrm{~mm}^{3}}
$$

\section{White blood cell count}

The total white blood cells were counted under the microscope using the haemocytometer. A white blood cell pipette was used to draw blood to 0.5 mark and diluted to 1.2 mark with the aid of the white cell diluting fluid. The leucocytes in the four lower squares were counted. The number of cells counted was calculated using the formula below:

$\mathrm{WBC}=\frac{\text { Total number of cell count } \mathrm{x} \text { dilution factor }}{\text { Volume } 0.4 \mathrm{~mm}^{3}}$

Others such as mean corpuscular haemoglobin $(\mathrm{MCH})$, mean corpuscular volume (MCV) and mean corpuscular haemoglobin concentration ( $\mathrm{MCHC}$ ) were obtained by calculation according to standard formulae (Schalm et al., 1975; Jain, 1986) as shown below:

$$
\begin{aligned}
& \mathrm{MCV}=\frac{\mathrm{PCV} \times 10}{\mathrm{EBC} \operatorname{count}\left(\mathrm{m} \times 10^{6} / \mathrm{mm}^{3}\right)} \\
& \mathrm{MCH}=\frac{\mathrm{Hb}(\mathrm{g} / \mathrm{dl}) \times 10}{\mathrm{RBC}\left(\mathrm{m} \times 10^{6} / \mathrm{mm}^{3}\right)} \\
& \mathrm{MCHC}=\frac{\mathrm{Hb}(\mathrm{g} / \mathrm{dl}) \times 10}{\mathrm{PCV}(\%)}
\end{aligned}
$$

To determine the biochemical parameters, blood samples were collected into plain sample bottles and allowed to clot and centrifuged at $1500 \mathrm{rpm}$ for $20 \mathrm{~min}$ to separate the sera. The sera samples were used for the biochemical parameters determination. The levels and activities of liver enzymes such as Alanine aminotransferase (ALT), Aspartate aminotransferase (AST) and Alkaline phosphatase (ALP), total protein, albumin, total bilirubin, cholesterol, HDL, LDL and triglyceride were determined according to the enzymatic colorimetric method described by Schmidt and Schmidt (1975) using a commercial diagnostic reagent kits (Randox Laboratories Ltd., UK).

\section{Statistical analysis}

The statistical software SAS version 9.1 (2003) was used to compare the differences among the treatments. Data was subjected to analysis of variance (ANOVA) and the means were separated using Duncan multiple range test, and values with $\mathrm{p}<0.05$ were considered statistically significant. 
Table 1. Growth parameters of Noiler birds administered extract at different inclusion levels.

\begin{tabular}{lcccc}
\hline Parameters & T1 & T2 & T3 & T4 \\
\hline AIW $(\mathrm{g})$ & $1970 \pm 90.5$ & $1950 \pm 107.3$ & $1920 \pm 68.0$ & $1970 \pm 75.8$ \\
AFW $(\mathrm{g})$ & $2590 \pm 116.1$ & $2640 \pm 109.7$ & $2692 \pm 73.7$ & $2591 \pm 78.9$ \\
AFI $(\mathrm{g})$ & $113 \pm 0.3$ & $114 \pm 1.4$ & $113 \pm 0.03$ & $113 \pm 0.6$ \\
DWG $(\mathrm{g})$ & $20.1 \pm 2.8$ & $20.7 \pm 2.0$ & $21.3 \pm 2.1$ & $17.9 \pm 2.9$ \\
FCR & $7.76^{\mathrm{a}} \pm 0.414$ & $8.30^{\mathrm{a}} \pm 0.871$ & $6.22^{\mathrm{b}} \pm 0.260$ & $7.67^{\mathrm{a}} \pm 0.255$ \\
\hline
\end{tabular}

Means within each column with different superscripts are significantly different $(P<0.05)$. AIW- Average Initial weight, $A F W$ Average Final Weight, AFI- Average Feed Intake, DWG- Daily Weight Gain, FCR- Feed Conversion Ratio.

\section{RESULTS AND DISCUSSION}

The growth performance indices of the noiler birds administered turmeric mixed with coconut oil are shown in Table 1. There was no significant difference in the average final weight of the birds in all the treatments $(2590 \pm 116.1$, $2640 \pm 109.7,2692 \pm 73.7,2591 \pm 78.9 \mathrm{~g})$ but treatment 3 (turmeric at $20 / \mathrm{kg}$ of feed) had the highest average final weight $(2692 \pm 73.7 \mathrm{~g})($ Table 1). There was no significant difference $(P>0.05)$ in the daily weight gain $(20.1 \pm 2.8$, $20.7 \pm 2.0,21.3 \pm 2.1,17.9 \pm 2.9 \mathrm{~g}$ ) across all treatments. The results obtained on body weight are in agreement with Emadi and Kermanshashi (2006) who reported that at an inclusion rate of $2.5,5$ and $7.5 \mathrm{~g} / \mathrm{kg}$ of diet, turmeric had no effect on weight gain of broiler chickens. However, this result contradicted Durrani et al. (2006) who found out that though at 2.5 and 10 levels, turmeric had no effect on body weight but at an inclusion of $5 \mathrm{~g} / \mathrm{kg}$, body weight was significantly higher. There was also no significant difference in the feed intake $(113 \pm 0.3,114 \pm 1.4,113 \pm 0.03$, $113 \pm 0.6 \mathrm{~g}$ ) across all treatments. This finding agrees with the reports of Emadi and Kermanshahi (2006), Durrani et al. (2006), Ahmadi (2010) and Nouzarian et al. (2011) who reported that the inclusion of Curcuma longa at different varying levels have no effect on feed intake. There was significant difference in the feed conversion ratio with birds administered turmeric at $20 \mathrm{~g} / \mathrm{kg}$ feed $(6.22 \pm 0.260)$ having the lowest and hence best feed conversion ratio $(P<0.05)$. This result is in agreement with Nouzarian et al. (2011) who reported the most efficient FCR in broilers fed diets supplemented with turmeric powder, but not with Durrani et al. (2006) who reported that chickens receiving diets supplemented with $5 \mathrm{~g} / \mathrm{kg}$ turmeric powder had better feed conversion ratio than 2.5 and $10 \mathrm{~g} / \mathrm{kg}$ supplementation level. Also, Ahmadi (2010) reported that inclusion of turmeric $(0.3$ and $0.6 \mathrm{~g} / \mathrm{kg})$ to the aflatoxin contaminated diets had no effect on feed intake, but significantly increased weight gain and improved feed conversion when compared with birds fed contaminated diets alone. According to Nouzarian et al. (2011) the impact of growth promoter substances, such as phytogenic products, on performance could be related to a more efficient use of nutrients, which in turn resulted in an improved FCR.

The hematological parameters of noiler chickens is shown in Table 2. That there were significant differences $(p<0.05)$ among the means of the pack cell volume $(\%)$, hemoglobin, red blood cells, lymphocytes, heterophils, monocytes, eosinophils and basophils. The PCV $(35.00 \pm 1.88)$ of birds fed $10 \mathrm{~g}$ of turmeric per $\mathrm{kg}$ of feed was significantly higher $(p<0.05)$ compared to birds in treatments T1 $(31.09 \% \pm 2.3)$, T3 $(33.17 \% \pm 0.79)$ and T4 $(31.33 \% \pm 2.23)$. The hemoglobin content of birds administered $10 \mathrm{~g}$ of turmeric per $\mathrm{kg}$ of feed $(11.48 \pm 0.67)$ was also significantly different when compared to birds in T1 (10.16 \pm 0.74$)$, T3 (10.78 \pm 0.30$)$ and T4 (10.50 \pm 0.71$)$ groups. This indicated that turmeric increased the levels of packed cell volume and hemoglobin in the blood. This was not in agreement with the result of the research conducted by Kafi et al. (2017) on broilers fed turmeric that, blood parameters (HB, PCV, ESR) were not significantly different to the control. Among the turmeric administered groups, the RBC were not significantly different [T2 (3.35 $\left.\mathrm{x} 10^{6} \pm 0.08 / \mathrm{l}\right)$, T3 $\left(3.38 \times 10^{6} \pm 0.04 / /\right)$ and T4 (3.35 x10 $\pm 0.14 / \mathrm{l})$ but there was significant different $(p<0.05)$ when compared to control birds T1 $\left(3.12 \times 10^{6} \pm 0.21 / /\right)$ ].

Lymphocytes count of the control birds $\left(10.29 \times 10^{3}\right.$ $\pm 0.17 / l)$ was significantly lower $(p<0.05)$ compared toother treatments. The heterophils of birds in the control $\left(4.684 \times 10^{3} \pm 1.06 / /\right)$ was significantly $(p<0.05)$ higher to other treatments while the monocytes of birds in T4 (0.673 $\left.\times 10^{3} \pm 0.04 / l\right)$ was significantly higher than birds in $\mathrm{T} 1$ $\left(0.626 \times 10^{3} \pm 0.08 / /\right)$, T2 $\left(0.556 \times 10^{3} \pm 0.03 / /\right)$ and T3 $(0.521$ $\left.\times 10^{3} \pm 0.04 / /\right)$. This was not in agreement with the study of Kumari et al. (2007) that for the lymphocytes, there was significant reduction in group fed curcumin than the control group, for the heterophils, the group fed curcumin was significantly higher than other groups and there was no significant difference in the monocyte count of the birds across all treatment.

The biochemical parameters of chickens are shown in Table 3. There were significant differences $(p<0.05)$ in total protein, alkaline phosphatase, total bilirubin, and cholesterol level across the treatments. The total proteins of animals fed turmeric supplemented diets T3 $(5.63 \pm 0.34)$ and T2 $(5.28 \pm 0.45)$ were significantly $(p<0.05)$ different to T1 $(5.03 \pm 0.48)$ and T4 birds $(4.93 \pm 0.40)$. This was in accordance with Gholami-Ahanquaran et al. (2016), who reported that total protein in chickens fed aflatoxin plus turmeric increased significantly. A decrease in total protein level may indicate severe malnutrition, disorders 
Table 2. Hematological parameters of noiler chickens administered turmeric powder.

\begin{tabular}{lcccc}
\hline Parameters & $\mathbf{T}_{1}$ & $\mathbf{T}_{2}$ & $\mathbf{T}_{3}$ & $\mathbf{T}_{4}$ \\
\hline PCV $(\%)$ & $31.09 \pm 2.39^{\mathrm{b}}$ & $35.00 \pm 1.88^{\mathrm{a}}$ & $33.17 \pm 0.79^{\mathrm{b}}$ & $31.33 \pm 2.23^{\mathrm{b}}$ \\
HB $(\mathrm{g} / \mathrm{dl})$ & $10.16 \pm 0.74^{\mathrm{b}}$ & $11.48 \pm 0.67^{\mathrm{a}}$ & $10.78 \pm 0.30^{\mathrm{b}}$ & $10.50 \pm 0.71^{\mathrm{b}}$ \\
RBC $\left(\mathrm{x} 10^{6} / \mathrm{l}\right)$ & $3.12 \pm 0.21^{\mathrm{b}}$ & $3.35 \pm 0.08^{\mathrm{a}}$ & $3.38 \pm 0.04^{\mathrm{a}}$ & $3.35 \pm 0.14^{\mathrm{a}}$ \\
WBC $\left(\times 10^{3} / \mathrm{l}\right)$ & $16.34 \pm 0.81$ & $16.71 \pm 0.51$ & $16.45 \pm 0.45$ & $16.82 \pm 0.47$ \\
PLATELET $\left(\mathrm{x} 10^{4} / \mathrm{l}\right)$ & $18.84 \pm 1.71$ & $16.50 \pm 1.24$ & $17.08 \pm 1.58$ & $17.45 \pm 1.85$ \\
LYM $\left(\mathrm{x} 10^{3} / \mathrm{l}\right)$ & $10.29 \pm 0.17^{\mathrm{b}}$ & $10.89 \pm 0.07^{\mathrm{a}}$ & $10.75 \pm 0.20^{\mathrm{a}}$ & $11.10 \pm 0.00^{\mathrm{a}}$ \\
HET $\left(\mathrm{x} 10^{3} / \mathrm{l}\right)$ & $4.684 \pm 1.06^{\mathrm{a}}$ & $4.678 \pm 0.10^{\mathrm{a}}$ & $4.441 \pm 0.34^{\mathrm{ab}}$ & $4.233 \pm 0.19^{\mathrm{b}}$ \\
MON $\left(\mathrm{x} 10^{3} / \mathrm{l}\right)$ & $0.626 \pm 0.08^{\mathrm{b}}$ & $0.556 \pm 0.03^{\mathrm{c}}$ & $0.521 \pm 0.04^{\mathrm{d}}$ & $0.673 \pm 0.04^{\mathrm{a}}$ \\
EO (x10 & $0.707 \pm 0.00^{\mathrm{a}}$ & $0.556 \pm 0.28^{\mathrm{b}}$ & $0.686 \pm 0.17^{\mathrm{a}}$ & $0.673 \pm 0.04^{\mathrm{a}}$ \\
BA $\left(\times 10^{3} / \mathrm{l}\right)$ & $0.028 \pm 0.00^{\mathrm{c}}$ & $0.028 \pm 0.00^{\mathrm{c}}$ & $0.054 \pm 0.00^{\mathrm{b}}$ & $0.139 \pm 0.05^{\mathrm{a}}$ \\
\hline
\end{tabular}

The values in the same row with different superscript are significantly different $(p<0.05)$. PCV: Packed cell volume, Hb: Haemoglobin, RBC: Red blood cell, WBC: White blood cell, LYM: Lymphotes, HET: Heterophils, MON: Monocytes, EO: Eosinophils, BA: Basophils.

Table 3. Biochemical parameters of noiler chickens administered turmeric powder.

\begin{tabular}{lcccc}
\hline Parameters & $\mathbf{T}_{1}$ & $\mathbf{T}_{2}$ & $\mathbf{T}_{3}$ & $\mathbf{T}_{\mathbf{4}}$ \\
\hline TOTAL PROTEIN $(\mathrm{g} / \mathrm{dl})$ & $5.03 \pm 0.48^{\mathrm{b}}$ & $5.28 \pm 0.45^{\mathrm{a}}$ & $5.63 \pm 0.34^{\mathrm{a}}$ & $4.93 \pm 0.40^{\mathrm{b}}$ \\
ALB $(\mathrm{g} / \mathrm{dl})$ & $1.50 \pm 0.41$ & $1.43 \pm 0.31$ & $1.65 \pm 0.24$ & $1.30 \pm 0.30$ \\
GLO $(\mathrm{g} / \mathrm{dl})$ & $3.53 \pm 0.15$ & $3.85 \pm 0.19$ & $4.08 \pm 0.17$ & $3.63 \pm 0.13$ \\
A/G RATIO & $0.38 \pm 0.11$ & $0.33 \pm 0.07$ & $0.38 \pm 0.06$ & $0.32 \pm 0.07$ \\
AST (U/l) & $200.25 \pm 2.29$ & $189.50 \pm 4.36$ & $198.00 \pm 3.82$ & $222.50 \pm 16.98$ \\
ALT (U/l) & $31.83 \pm 3.36$ & $31.17 \pm 3.95$ & $37.00 \pm 3.08$ & $33.50 \pm 5.71$ \\
ALP (U/l) & $197.83 \pm 5.99^{\mathrm{b}}$ & $228.33 \pm 4.57^{\mathrm{a}}$ & $213.67 \pm 6.71^{\mathrm{ab}}$ & $191.50 \pm 2.66^{\mathrm{b}}$ \\
TOTAL BIL (mg/dl) & $2.02 \pm 1.13^{\mathrm{b}}$ & $4.50 \pm 0.92^{\mathrm{a}}$ & $4.03 \pm 0.97^{\mathrm{a}}$ & $3.38 \pm 1.23^{\mathrm{a}}$ \\
CHOL (mg/dl) & $172.25 \pm 3.64^{\mathrm{a}}$ & $163.17 \pm 6.30^{\mathrm{bc}}$ & $166.33 \pm 6.47^{\mathrm{b}}$ & $170.17 \pm 2.89^{\mathrm{ab}}$ \\
HDL $(\mathrm{mg} / \mathrm{dl})$ & $121.92 \pm 2.14$ & $117 \pm 5.93$ & $123.17 \pm 4.36$ & $117.83 \pm 8.02$ \\
LDL $(\mathrm{mg} / \mathrm{dl})$ & $36.87 \pm 2.99$ & $34.23 \pm 8.09$ & $27.27 \pm 5.15$ & $41.27 \pm 7.81$ \\
TRIG $(\mathrm{mg} / \mathrm{dl})$ & $67.33 \pm 3.57$ & $59.67 \pm 7.25$ & $64.67 \pm 7.84$ & $55.33 \pm 3.53$ \\
\hline
\end{tabular}

The values in the same row with different superscript are significantly different $(p<0.05)$. ALB: Albumin, GLO: Globulin, AST: aspartate transferase, TRIG: triglyceride, CHOL: cholesterol, HDL: high-density lipoprotein, LDL: low-density lipoprotein, ALT: alanine aminotransferase, ALP: alkaline phosphatase, A/G RATIO: Albumin/Globulin ratio.

associated with mal-absorption such as celiac or hepartic disease which interferes with protein metabolism (Stuart 2011). Nandan and Vipin (2014) also reported that turmeric supplementation improved the level of total protein. Higher total protein level suggested better ability of the hepatocytes of group fed turmeric to synthesize protein (Kumari et al., 2007). Alkaline phosphatase was significantly $(p<0.05)$ different across the treatments, T2 $(228.33 \pm 4.57)$ had the highest value while T4 birds recorded the lowest value $(191.50 \pm 2.66)$. The total bilirubin of T1 $(2.02 \pm 1.13)$ was significantly $(p<0.05)$ lower compared with T2 $(4.50 \pm 0.92)$, T3 $(4.03 \pm 0.97)$ and T4 (3.38 \pm 1.23$)$. This was in agreement with Kaur et al. (2006) who reported that treatment with Curcuma longa significantly and dose-dependently decreased the lipopolysaccharide (LPS) induced elevated levels of AST, ALT, ALP and bilirubin in serum. Albumin, Globulin,
Albumin/Globulin ratio, Aspartate aminotransferase, Alanine aminotransferase were not significantly $(p>0.05)$ different across the treatments and was not in conformity with Nandan and Vipin (2014) who reported that turmeric supplementation improved the levels of albumin, globulin and restored the liver functions (AST, ALT and ALP). Cholesterol was significantly $(p<0.05)$ different across the treatments, the animal fed diets supplemented with turmeric T2 (163.17 $\pm 6.30 \mathrm{mg} / \mathrm{dl})$ and T3 (166.33 \pm 6.47 $\mathrm{mg} / \mathrm{dl}$ ) had significantly low cholesterol values compared with T4 $(170.17 \pm 2.89 \mathrm{mg} / \mathrm{dl})$ and T1 $(172.25 \pm 3.64 \mathrm{mg} / \mathrm{dl})$ birds. This was in agreement with Asai and Miyazawa (2001) who examined the effect of curcumin on lipid metabolism in rats fed a moderately high-fat diet they found out that liver triacylglycerol and cholesterol concentrations were significantly lower in rats fed curcumin than in control animals. These findings were in 
contrast with the results of Emadi et al. (2007) who reported that turmeric supplementation into the basal diets of broiler chickens significantly increased total cholesterol and HDL-cholesterol and decreased LDL-cholesterol, but did not affect total triglyceride, total protein and haematocrit value. LDL, HDL and triglyceride values reported in this study were in agreement with Mehala and Moorthy (2008) as they were not significantly affected with turmeric supplementation.

\section{Conclusion}

Considering the results obtained in the current study it could be concluded that Curcuma longa powder does not increase body weight gain but it has the potential to improve feed conversion ratio; turmeric has ability to increase packed cell volume, hemoglobin and red blood cells. It also has ability to increase high density lipoprotein and reduce the level of low density lipoprotein of cholesterol, hence can be included in the feed of noiler birds up to $20 \mathrm{~g} / \mathrm{kg}$. However, more work needs to be done on this combination using younger animals.

\section{CONFLICT OF INTEREST}

The authors declare that they have no conflict of interest.

\section{REFERENCES}

Adene, D. F., \& Oguntade, A. E. (2006). The structure and importance of the commercial and village based poultry industry in nigeria, FAO (rome) study. P. 1

Adodo, A. (2002). Medicinal value of coconut. Nature Power: A Christian Approach of Herbal Medicine. Don Bosco Printing, Akure, p. 207.

Aggarwal, S., Takada, Y., Singh, S., Myers, J. N., \& Aggarwal, B. B. (2004). Inhibition of growth and survival of human head and neck squamous cell carcinoma cells by curcumin via modulation of nuclear factor-kB signaling. International Journal of Cancer, 111(5), 679-692.

Ahmad, M. Z., Alkahtani, S. A., Akhter, S., Ahmad, F. J., Ahmad, J., Akhtar, M. S., Mohsin, N., \& Abdel-Wahab, B. A. (2016). Progress in nanotechnology-based drug carrier in designing of curcumin nanomedicines for cancer therapy: current state-ofthe-art. Journal of drug targeting, 24(4), 273-293.

Ahmadi, F. (2010). Effect of turmeric (Curcumin longa) powder on performance, oxidative stress state and some of blood parameters in broiler fed on diets containing aflatoxin B1. Global Veterinaria, 5(6), 312-317.

Anwarul, H. G., Abdul, J., Muhammad, N., \& Kashif, M. (2006). Pharmacological basis for the use of turmeric in gastrointestinal and respiratory disorders. Life Science, 76, 3089-3105.

Asai, A., \& Miyazawa, T. (2001). Dietary curcuminoids prevent high-fat diet-induced lipid accumulation in rat liver and epididymal adipose tissue. The Journal of nutrition, 131(11), 2932-2935.

Durrani, F. R., Ismail, M., Sultan, A., Suhail, S. M., Chand, N., \&
Durrani, Z. (2006). Effect of different levels of feed added turmeric (Curcuma longa) on the performance of broiler chicks. Journal of Agricultural and Biological Science, 1(2), 911.

Emadi, M., \& Kermanshahi, H. (2006). Effect of turmeric rhizome powder on performance and carcass characteristics of broiler chickens. International Journal of Poultry Science, 5(11), 10691072.

Emadi, M., Kermanshahi, H., \& Maroufyan, E. (2007). Effect of varying levels of turmeric rhizome powder on some blood parameters of broiler chickens fed corn-soybean meal based diets. Int. J. Poult. Sci., 6(5), 345-348.

Gholami-Ahangaran, M., Rangsaz, N., \& Azizi, S. (2016). Evaluation of turmeric (Curcuma longa) effect on biochemical and pathological parameters of liver and kidney in chicken aflatoxicosis. Pharmaceutical biology, 54(5), 780-787.

Girish, C., \& Pradhan, S. C. (2012). Hepatoprotective activities of picroliv, curcumin, and ellagic acid compared to silymarin on carbon-tetrachloride-induced liver toxicity in mice. Journal of pharmacology \& pharmacotherapeutics, 3(2), 149-155.

Hrabčáková,P., Voslářová, E.,Bedáňová, I., Pištěková, V., Chloupek,J. and Vladimír, V.(2014). Haematological and Biochemical Parameters during the Laying Period in Common Pheasant Hens Housed in Enhanced Cages. The Scientific World Journal Volume 2014, Article ID 364602, 6 pages.

Jain, N. C. (1986). Schalm's Veterinary Hematology, $4^{\text {th }}$ edition. Lea and Febiger, 600, Washington square, Philadelphia, USA.

Kafi, A., Uddin, M. N., Uddin, M. J., Khan, M. M. H., \& Haque, M. E. (2017).Effect of Dietary Supplementation of Turmeric (Curcuma longa), Ginger (Zingiber officinale) and their Combination as Feed Additives on Feed Intake, Growth Performance and Economics of Broiler . International Journal of Poultry Science, 16 (7), 257-265.

Kaur, G., Tirkey, N., Bharrhan, S., Chanana, V., Rishi, P., \& Chopra, K. (2006). Inhibition of oxidative stress and cytokine activity by curcumin in amelioration of endotoxin-induced experimental hepatoxicity in rodents. Clinical and Experimental Immunology, 145(2), 313-321.

Kim, M., \& Kim, Y. (2010). Hypocholesterolemic effects of curcumin via up-regulation of cholesterol 7a-hydroxylase in rats fed a high fat diet. Nutrition Research and Practice, 4(3), 191-195.

Kumari, P, Gupta, M. K., Ranjan, R., Singh, K. K., \& Yadava, R. (2007). Curcuma longa as feed additive in broiler birds and its patho-physiological effects. Indian Journal of Experimental Biology, 45, 272-277.

Lal, J., Gupta, S. K., Thavaselvam, D., \& Agarwal, D. D. (2012). Design, synthesis, synergistic antimicrobial activity and cytotoxicity of 4-aryl substituted 3, 4-dihydropyrimidinones of curcumin. Bioorganic \& medicinal chemistry letters, 22(8), 2872-2876.

Lee, S. H., Lillehoj, H. S., Jang, S. I., Lillehoj, E. P., Min, W., \& Bravo, D. M. (2013). Dietary supplementation of young broiler chickens with Capsicum and turmeric oleoresins increases resistance to necrotic enteritis. British Journal of Nutrition, 110(5), 840-847.

Mehala, C., \& Moorthy, M. (2008). Production performance of broilers fed with Aloe vera and Curcuma longa (Turmeric). Int. J. Poult. Sci, 7(9), 852-856.

Mishra, S., Karmodiya, K., Surolia, N., \& Surolia, A. (2008). Synthesis and exploration of novel curcumin analogues as anti-malarial agents. Bioorganic \& medicinal chemistry, 16(6), 2894-2902.

Nandan, A., \& Vipin, (2014). Bioremedial effect of Curcuma longa 
on endosulfan induced kidney and liver of swiss albino mice. Indian Journal of Biotechnology and Pharmaceutical Research, 2, 23-27.

Nouzarian, R., Tabeidian, S. A., Toghyani, M., Ghalamkari, G., \& Toghyani, M. (2011). Effect of turmeric powder on performance, carcass traits, humoral immune responses, and serum metabolites in broiler chickens. Journal of Animal and Feed Sciences, 20, 389-400.

Omojasola, P. F. \& Awe, S. (2004). The antibacterial activity of the leaf extracts of Anacardiumoccidentaleand Gossypiumhirsutunagainst some selected microorganisms. Bioscience Research Communications, 60(1), 25-58.

Rahmani, A. H., Alsahli, M. A., Aly, S. M., Khan, M. A., \& Aldebasi, Y. H. (2018). Role of Curcumin in Disease Prevention and Treatment. Advanced biomedical research, 7, 38.

Renter, E. (2013). How to Optimize Turmeric Absorption for Super-Boosted? Available at http://naturalsociety.com/turmeric-absorption-super-benefitsblack-pepper

Schalm, O. W., Jain, N. C., \&Caroll, E. J. (1975). Veterinary Haematology. 3rd Edn., Lea and Fabiger, Philadelphia. Pp. 15218.
Si, W., Gong, J., Tsao, R., Zhou, T., Yu, H., Poppe, C., Johnson, R., \& Du, Z. (2006). Antimicrobial activity of essential oils and structurally related synthetic food additives towards selected pathogenic and beneficial gut bacteria. Journal of Applied Microbiology, 100(2), 296-305.

Singh, R. K., Rai, D., Yadav, D., Bhargava, A., Balzarini, J., \& De Clercq, E. (2010). Synthesis, antibacterial and antiviral properties of curcumin bioconjugates bearing dipeptide, fatty acids and folic acid. European journal of medicinal chemistry, 45(3), 1078-1086.

Stuart, I. F. (2011). A Laboratory Guide to Human Physiology: Concepts and Clinical Applications 14th Edition ISBN: 0077296176 McGraw-Hill Science/Engineering/Math.

Trujillo, J., Chirino, Y. I., Molina-Jijón, E., Andérica-Romero, A. C., Tapia, E., \& Pedraza-Chaverrí, J. (2013). Renoprotective effect of the antioxidant curcumin: Recent findings. Redox Biology, 1(1), 448-456.

Windisch, W., Schedle, K., Plitzner, C., \& Kroismayr, A. (2008). Use of phytogenic products as feed additives for swine and poultry 1. Journal of animal science, 86(14 suppl), E140-E148. 